\title{
Plankton community dynamics in a subtropical lagoonal system and related factors
}

\author{
LETÍCIA DONADEL ${ }^{1}$, LUCIANA DE S. CARDOSO ${ }^{1}$ and LEZILDA C. TORGAN ${ }^{1,2}$ \\ ${ }^{1}$ Programa de Pós-Graduação em Botânica, Universidade Federal do Rio Grande do Sul, Avenida \\ Bento Gonçalves, 9500, Campus do Vale, 91501-970 Porto Alegre, RS, Brasil \\ ${ }^{2}$ Fundação Zoobotânica do Rio Grande do Sul, Museu de Ciências Naturais, Rua Salvador \\ França, 1427, Jardim Botânico, 90690-000 Porto Alegre, RS, Brasil
}

Manuscript received on January 13, 2015; accepted for publication on May 18, 2015

\begin{abstract}
Changes of the plankton community in a shallow, subtropical lagoonal system and its relation to environmental conditions were investigated during an annual cycle to provide information on its spatial and seasonal variation pattern. The study carried out at four sites (three in the Peixe lagoon and one in the Ruivo lagoon), which are located in the Lagoa do Peixe National Park, southern Brazil. The system has a temporary connection to the Atlantic Ocean by a narrow channel. The phytoplankton density was higher in the Peixe lagoon whereas the specific richness was higher in the Ruivo lagoon which is also a site with the lower salinity. The phytoplankton biomass near the channel showed seasonal variation with the highest value in fall and lowest in winter. Zooplankton richness was inversely correlated with salinity, and had the highest values in the Ruivo lagoon. Ordination analysis indicated seasonal and spatial patterns in plankton community in this lagoonal system, related to variation in salinity. In addition, the wind action and precipitation were important factors on the spatial and seasonal salinity changes in the lagoon with direct influence on the plankton community dynamics.
\end{abstract}

Key words: coastal lagoon, microalgae, Ramsar site, South Brazil.

\section{INTRODUCTION}

Spatial and seasonal heterogeneity of phytoplankton are regular features in coastal lagoons in different parts of the world, and has been the focus of studies in temperate (Armi et al. 2010, Chapman et al. 1998, Ramdani et al. 2009), tropical (Melo and Suzuki 1998, Melo et al. 2007, Varona-Cordero et al. 2010), and subtropical zones (Bergesch and Odebrecht 1987, Callegaro et al. 1981, Conde and Sommaruga 1999, Odebrecht and Abreu 1998,

Correspondence to: Letícia Donadel

E-mail: leticiadonadel@yahoo.com.br
Odebrecht et al. 2010a, Torgan 1997, Torgan et al. 2000, 2006). These systems fluctuate between freshwater and hypersaline conditions (Kjerfve 1994), related to the inflow of seawater or fresh water, as well as to wind action (salt spray). Moreover, wind velocity and direction may influence the magnitude of sediment resuspension and water exchange, modifying water chemistry and physical characteristics (Muller et al. 1991).

Although coastal lagoons are important environments, both ecologically and economically, only a relatively small number of studies have been carried out in subtropical and in permanently 
enclosed coastal lagoons (Hennemann and Petrucio 2011). Phytoplankton community structure of subtropical lagoons is related to the spatial salinity gradient (Callegaro et al. 1981, Conde and Sommaruga 1999, Torgan 1997, Torgan et al. 2000). In addition, the spatial heterogeneity of subtropical shallow lake plankton is strongly influenced by hydrodynamics, while seasonality impacts community composition (Cardoso and Motta Marques 2004a, b, 2009, Crossetti et al. 2012). In some tropical lagoons, spatial variation in species composition occurred due to changes in salinity and nutrients, caused by the opening and closing of channels (Melo and Suzuki 1998, Melo et al. 2007) or other environmental variables, mainly salinity (Varona-Cordero et al. 2010).

The composition of phytoplankton in temperate zones has been driven more strongly by seasonality than by spatial changes in salinity (Ramdani et al. 2009). In the southern Mediterranean, community structure was associated with physico-chemical factors, especially with the seasonal variation of temperature and salinity (Armi et al. 2010). Seasonal fluctuations in abundance were observed for many species even in an environment that varies little in salinity (limnetic/oligohaline) (Chapman et al. 1998). In the Patos lagoon, density, chlorophyll $a$ and phytoplankton composition patterns are associated with changes in temperature, salinity and dissolved inorganic nutrients, and are besides related to light availability and precipitation (Odebrecht et al. 2005, 2010a, Torgan et al. 2006). Similarly, in Targus estuary, where air temperature, river flow and irradiance were major drivers of seasonal phytoplankton patterns (Gameiro et al. 2007).

Studies in tropical estuaries also suggest that seasonality influences phytoplankton composition, density and biomass: the exchange between marine and coastal waters during monsoon periods influences salinity and the spatial and temporal distribution of nutrients (Matos et al. 2011, Yin 2002).
Our study was conducted in a shallow subtropical lagoonal system located in the coastal plain of the Rio Grande do Sul state, Brazil, which has a temporary connection to the Atlantic Ocean. The hypothesis of this study is that the structure and dynamic of the phytoplankton and zooplankton in this system are controlled by the hydrodynamics and salinity as observed in the other coastal lagoons from subtropical zones. Therefore, our aim was to identify the spatial and seasonal changes of plankton in a subtropical lagoonal system and the relation between abiotic factors and community dynamics.

The knowledge about microalgae in Peixe lagoonal system was limited to investigations about cyanobacteria (Werner 2002, Werner and Sant'Anna 2000, 2006) and fossil diatom assemblage (Santos 2011). Thus, the recognized ecological importance and the lack of research into plankton dynamics justify this study.

\section{MATERIALS AND METHODS}

\section{STUDY AREA}

The lagoons are located in the Lagoa do Peixe National Park and its connection with the sea allows the migration of many species, making it an important refuge for the reproduction and feeding of fishes and crustaceans. In addition, it is an important habitat for many birds on their route between North America and Patagonia and for resident birds (Knak 1999, Schäfer et al. 2009). This park is a major wetland conservation unit, being the only Ramsar site in Southern Brazil. It is also a Atlantic Forest Biosphere Reserve (UNESCO) in addition to being part of the Western Hemisphere Shorebird Reserve Network (WHSRN) (Knak 1999). Currently, the management of the park is under the direction of the Chico Mendes Institute for Biodiversity Conservation (ICMbio, Instituto Chico Mendes de Conservação da Biodiversidade) and the municipalities of Mostardas and Tavares. 
The Peixe lagoon is an elongated shallow water body (approximately $35 \mathrm{~km}$ long and $1 \mathrm{~km}$ wide, depth $<30 \mathrm{~cm}$ ). Its maximum depth (about 2 $\mathrm{m})$ is found near the mouth of the channel, which connects the lagoon to the sea. Ruivo lagoon, a small oligohaline water body, is connected to the northern end of the Peixe lagoon (Fig. 1). The margins of the Peixe lagoon are covered by extensive salt marshes of Paspalum vaginatum Sw., Cotula coronopifolia L., Spartina densiflora Brongn., Hydrocotyle bonariensis Lam., Androtrichum trigynum (Spreng.) H. Pfeiff., Bacopa monnieri (L.) Wettst. and Juncus acutus L.. These species are present with different vegetation associations in each sampling site (Costa and Tagliani 2011, Knak 1999).

\section{SAMPLING}

Plankton samples $(n=16)$ were collected at three sites in the Peixe lagoon, North $\left(31^{\circ} 15^{\prime} 37.68^{\prime \prime} \mathrm{S}\right.$, $\left.50^{\circ} 58^{\prime} 02.49^{\prime \prime} \mathrm{W}\right)$, Central $\left(31^{\circ} 21^{\prime} 17.84^{\prime \prime} \mathrm{S}\right.$, $51^{\circ} 02^{\prime} 49.72$ 'W), and South $\left(31^{\circ} 26^{\prime} 25.19^{\prime} \mathrm{S}\right.$, $\left.51^{\circ} 09^{\prime} 45.24^{\prime \prime} \mathrm{W}\right)$, and at one location at the Ruivo lagoon (31 13 '09.84'S, 50 55'50.95'W), in austral fall (June 2011), winter (August 2011), spring (November 2011) and summer (February 2012). Sampling sites are referred to as Px-N, Px-C, Px-S and Rvo, respectively (Fig. 1). Px-C is closer to the channel, less than $1.5 \mathrm{~km}$ from the sea, and $\mathrm{Px}-\mathrm{N}$ and Px-S are distant located at the opposite extremities of the lagoon, about $14 \mathrm{~km}$ from the channel. Ruivo lagoon is the farthest site from the sea (about $19 \mathrm{~km}$ ), connected to the system through channels and wetlands to the northern area of the Peixe lagoon.

\section{ABIOTIC VARIABLES}

Conductivity $\left(\mathrm{mS} . \mathrm{cm}^{-1}\right)$, salinity, $\mathrm{pH}$, water temperature $\left({ }^{\circ} \mathrm{C}\right)$, dissolved oxygen - DO $\left(\mathrm{mg} . \mathrm{L}^{-1}\right)$, and oxidation-reduction potential - ORP $\left(\mathrm{mg} . \mathrm{L}^{-1}\right)$ were measured with a HORIBA U52 probe. Depth and water transparency $(\mathrm{cm})$ were measured with a Secchi disk. Precipitation, wind velocity and wind direction data were obtained from the National Institute of Meteorology - INMET. We obtained these data on sampling dates including seven days prior.

Laboratory analyses were performed as follows: total phosphorus - TP (mg. $\left.\mathrm{L}^{-1}\right)$ by absorptiometry reduction of ascorbic acid (APHA 1998), total nitrogen - TN (mg. $\left.\mathrm{L}^{-1}\right)$, according to the Kjeldahl method (NBR 10560-1988, 13796-1997), and total silicate $\left(\mathrm{mg} . \mathrm{L}^{-1}\right)$ with the silico molybdate method

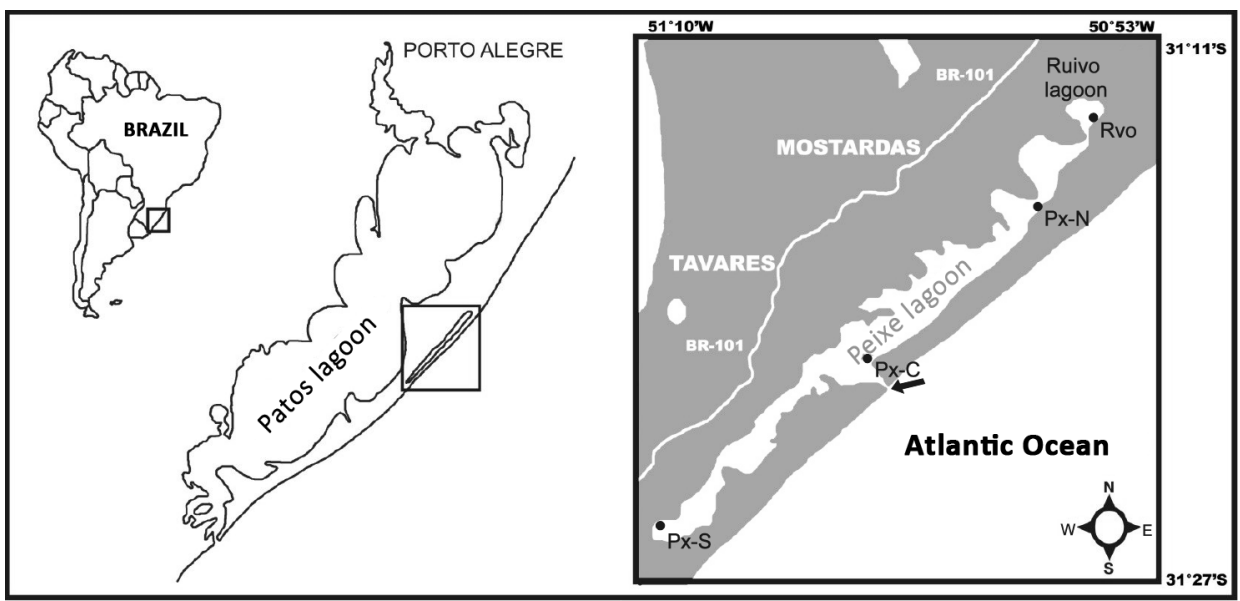

Figure 1 - Map of the Peixe and Ruivo lagoons with sampling locations (Adapted from Loebmann and Vieira 2006), arrow indicates the location of the sand bar. Peixe lagoon, North (Px-N), Center (Px-C), South (Px-S) and Ruivo lagoon (Rvo). 
(APHA 1998). The classification of salinity was based on the Venice System (Anonymous 1959). Trophic level was determined by the modified system of Vollenweider (Wetzel 1993).

\section{PLANKTON}

Phytoplankton samples were collected with bottles and a plankton net $(25 \mu \mathrm{m}$ mesh), and fixed respectively with neutral Lugol's solution and $4 \%$ formaldehyde. Diatom samples were washed and oxidized with potassium permanganate $\left(\mathrm{KMnO}_{4}\right)$ and hydrochloric acid $(\mathrm{HCl})$, according to Simonsen (1974), modified by Moreira-Filho and ValenteMoreira (1981).

Phytoplankton density (ind. $\mathrm{mL}^{-1}$ ) was estimated using the Utermöhl (1958) method in $10 \mathrm{~mL}$ sedimentation chambers. The counting efficiency was at least $80 \%$ (Pappas and Stoermer 1996) and only individuals with plastids were quantified. Dominance and abundance were determined according to Lobo and Leighton (1986). Specific richness was estimated from the number of taxa at generic and infra-specific level, and species diversity was assessed using the Shannon index (H') (Shannon and Weaver 1949). Biovolume $\left(\mathrm{mm}^{3} . \mathrm{L}^{-1}\right)$ was calculated using Hillebrand's approximate geometric models (Hillebrand et al. 1999), with fresh weight expressed as mass $\left(1 \mathrm{~mm}^{3} \cdot \mathrm{L}^{-1}=1 \mathrm{mg} \cdot \mathrm{L}^{-1}\right.$; Wetzel and Likens 2000$)$. Chlorophyll $a$ was measured by PHYTO-PAM chlorophyll fluorometer (Heinz Walz GmbH, Effeltrich, Germany) to determine the respective concentrations of phytoplankton groups.

For zooplankton analysis, 100L of water were concentrated into $100 \mathrm{~mL}$ using a plankton net (25 $\mu \mathrm{m}$ mesh). Samples were preserved in $4 \%$ formaldehyde solution, and subsequently quantified using a Sedgewick-Rafter chamber (APHA 1998). The volume of analyzed material ranged from 0.5 $\mathrm{mL}$ to $1 \mathrm{~mL}$, reaching a sample efficiency of at least 70 \% (Pappas and Stoermer 1996).

\section{DATA ANALYSES}

The spatial and seasonal distribution of the sample units were related to abiotic factors using Principal Component Analysis (PCA) and included 13 environmental variables. The relationship between biotic and abiotic variables with Canonical Correspondence Analysis (CCA) and Redundancy Analysis (RDA) that included only the abundant species according to Lobo and Leighton (1986). Data were transformed to $\log 10(\mathrm{x}+1)$ in order to normalize variances (Ter Braak 1986). A Monte Carlo permutation test was carried out to assess the significance of the ordination axes. The software Statistica ${ }^{\circledR}$ version 5.0 was used for descriptive analyses and r-Pearson correlation $(p<0.05)$. The software Pc-Ord ${ }^{\circledR}$ version 8.6 (McCune and Mefford 2011) was used for multivariate analyses (PCA, CCA and RDA).

\section{RESULTS}

\section{ENVIRONMENTAL CONDITIONS}

During the week of each seasonal sampling, precipitation was lower in spring and fall, 1.58 $( \pm 4.66)$ and $2.33( \pm 4.86) \mathrm{mm}$, respectively, and higher in winter and summer, $3.73( \pm 5.35)$ and $5.31( \pm 8.94) \mathrm{mm}$, respectively (Fig. 2a). The wind direction in fall varied mainly from $\mathrm{S}$ to $\mathrm{NW}$ on sampling days. In winter, winds varied from NE to SW, with a predominance of southerly winds. In spring, winds from the E quadrant prevailed, varying from NE to W. The highest hourly variation of wind direction was observed in summer. However, winds were most persistent from the NE quadrant on sampling days. The average wind velocities in winter and spring were $6.16( \pm 1.40)$ and $6.17( \pm$ $1.98) \mathrm{m} . \mathrm{s}^{-1}$, and $4.24( \pm 1.47)$ and $3.92( \pm 1.00) \mathrm{m}^{-\mathrm{s}^{-1}}$ in fall and summer, respectively (Fig. 2b).

The channel was open throughout the year of 2010, while in 2011 it was closed after the fall sampling, when a small connection with the sea 

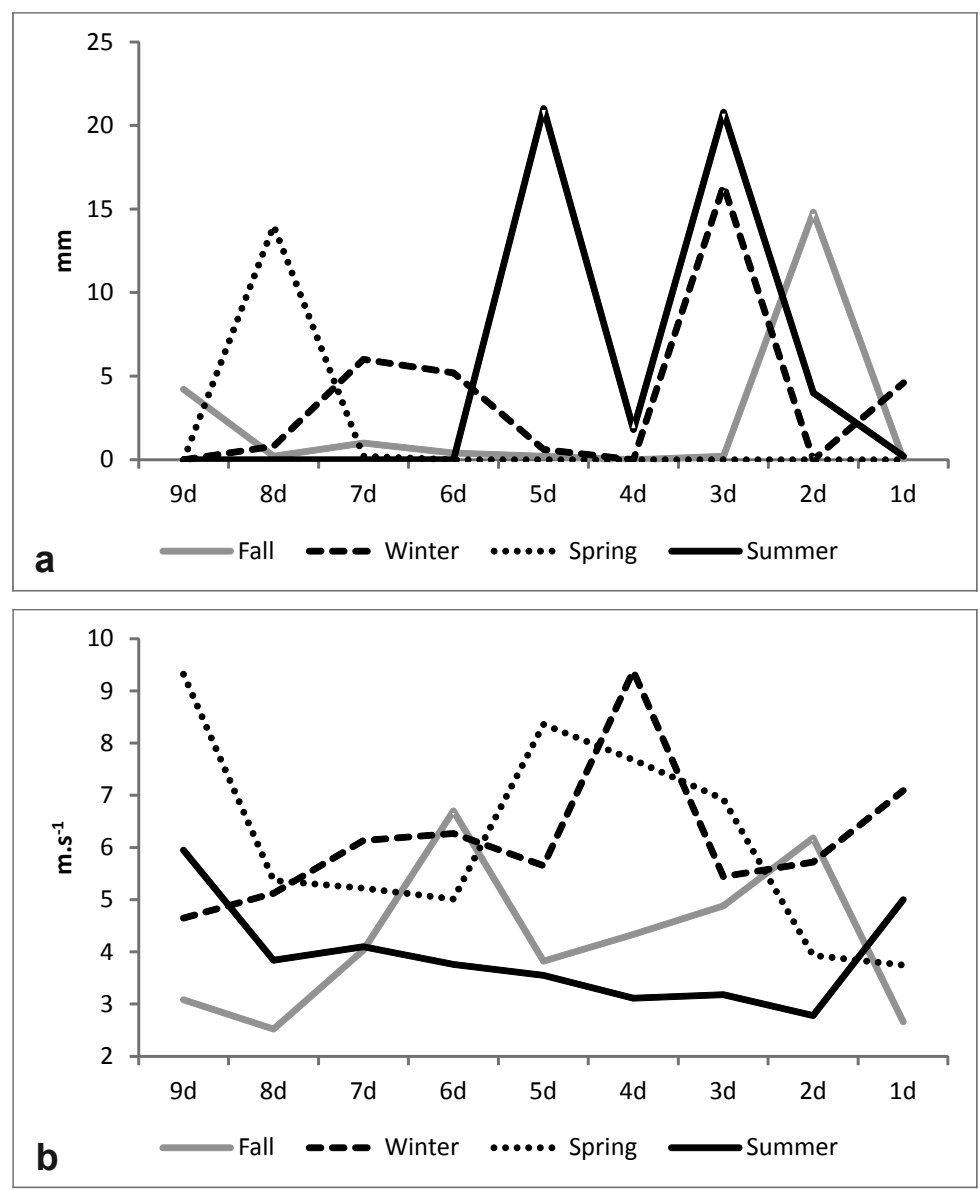

Figure 2 - Precipitation (a) and wind velocity (b) during the 7 days (d) before the sampling dates (1d and $2 \mathrm{~d}$ ).

still remained. The channel was artificially opened in early winter (2 August 2011), and remained open during the season. The connection of the lagoon with the ocean influenced the salinity of the system. The fall samples showed the highest saline waters uniformly throughout the system, and even Rvo and Px-S were mesohaline, while lower salinities and highest silicate and DO values were observed in winter. As expected, the lowest values of salinity were measured at Rvo (0.5) and Px-S (0.2), sites farther from the channel. Concerning TP, the lagoon varied from eutrophic to hyper-eutrophic, except in Px-S where it was always hyper-eutrophic. $\mathrm{TN}$ varied from predominantly mesotrophic to eutrophic in fall, winter and summer samples, and oligotrophic at all points in spring sample. The values of physical and chemical variables at the sample sites are shown in Table I.

The environmental variables (Table I except depth), excepting TP and Secchi, 11 were significantly related to the first and second axis from Principal Component Analysis (PCA), which explained $74.09 \%$ of the variance. Only the first axis was significant ( $p=0.001$ ) (Fig. 3). On the negative axis end we observed a spatial trend, where Px-C samples, closest to the channel, were grouped by salinity and conductivity. On the positive axis end we observed a seasonal trend, with winter samples grouped at high values of DO and silica. The oxidation-reduction potential also contributed to the grouping of samples of Rvo. Higher salinity was also observed at Px-N and Px-S in summer and at $\mathrm{Px}-\mathrm{N}$ in fall. 


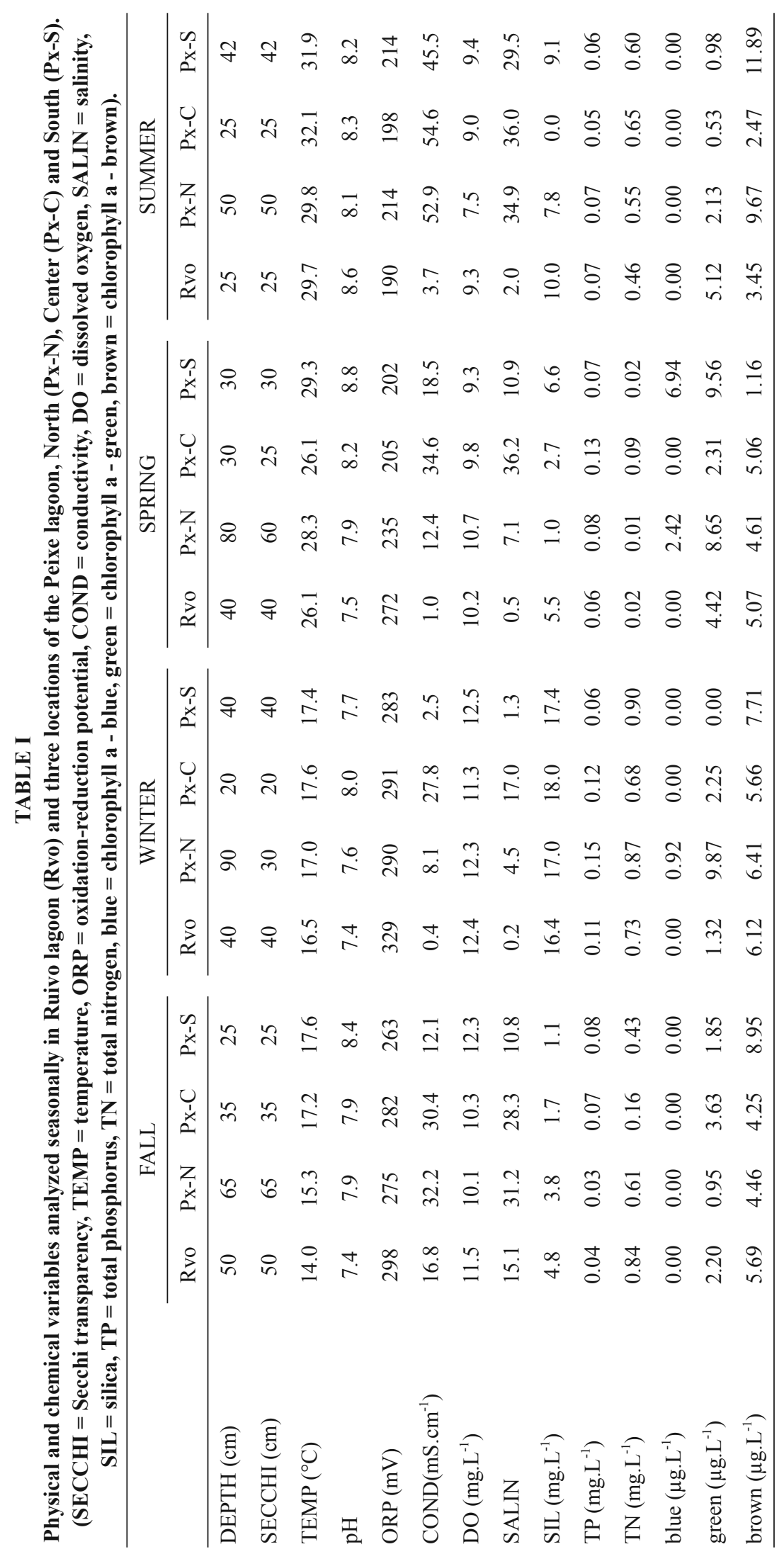




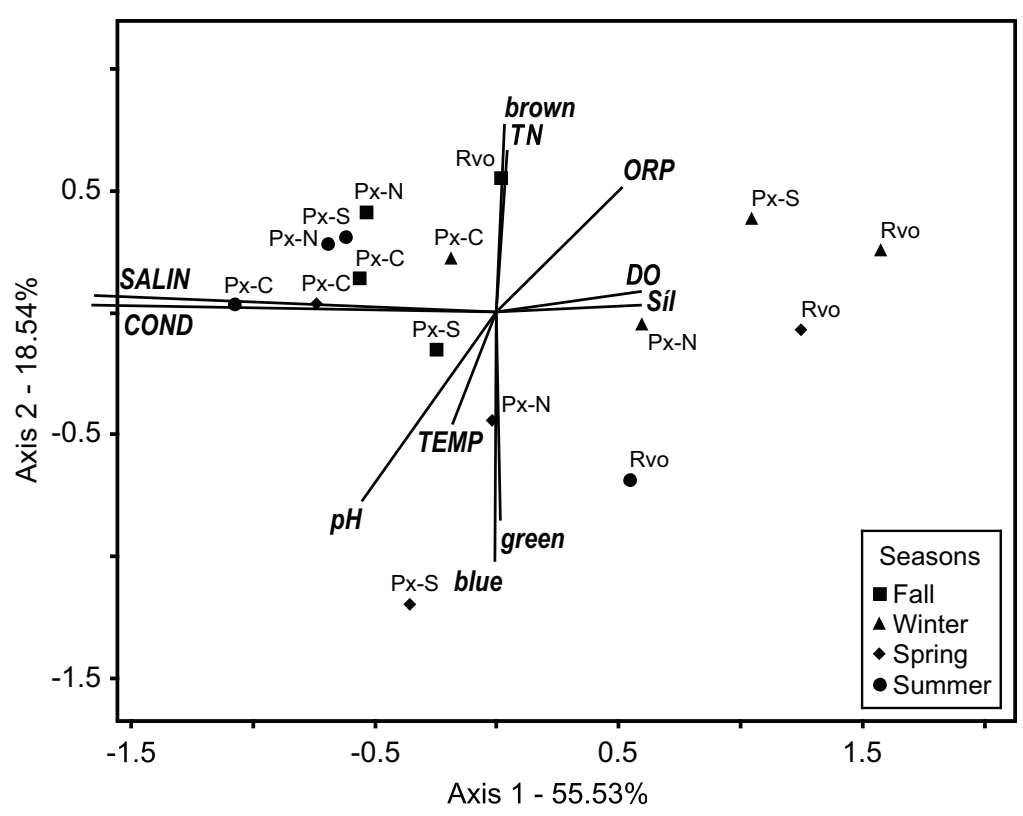

Figure 3 - Principal Component Analysis (PCA). Ordination diagram of the physical and chemical variables of different seasons in the Ruivo and Peixe lagoon. (Legend for locations and variables see Table I).

\section{PHYTOPLANKTON}

The phytoplankton community of both lagoons was composed of 136 taxa of the classes Bacillariophyceae (64), Chlorophyceae (30), Cyanobacteria (12), Cryptophyceae (6), Dinophyceae (6), Euglenophyceae (2), Chrysophyceae (1) and other phytoflagellates (15). The phytoplankton richness decreased from winter to summer samples (Fig. 4a) and was correlated with temperature $(-0.52), \mathrm{pH}$ $(-0.64)$ and DO (0.56). Spatially, specific richness was highest at Rvo and increased from Px-N to Px-S (Fig. 4b), thus showing the increment of specific richness at the end sites of the system, where sea influence was lower.

Phytoplankton density ranged from 653 to 114,829 ind. $\mathrm{mL}^{-1}$, and was in general uniformly distributed among the seasons (Fig. 4c), but presented a spatial pattern (Fig. 4d), with the exception of fall. In the fall, the environment was more homogeneous (low precipitation and channel closing). Spatially, the density was low in Px-C, close to the channel, independent of the season
(Fig. 4d). Phytoplankton biomass was highest at $\mathrm{Px}-\mathrm{C}$ in fall samples due to a bloom of Euglena sp. (23.86 mg.L $\mathrm{L}^{-1}$ ) (Figs. 4e and 4f). The total phytoplankton density and biomass were not significantly correlated with any chemical variable, showing that the spatial and seasonal tendency of this dynamic environment was better explained by the variation of the species composition.

The values of the specific diversity according to density and biomass showed little variation (mean around 1.8 bits.ind $^{-1}$ and 1.4 bits.mg. ${ }^{-1}$ ) in the seasonal samplings (Figs. 4g and 4i), whereas spatially the density diversity was higher at Rvo (2.0 bits.ind $^{-1}$ ) (Figs. 4h and 4j).

Diatoms and cyanobacteria were the most abundant groups in terms of density (Fig. 5a). Only in fall samples the sites appeared to be spatially heterogeneous with a different dominant group at each sampling site. In samples from other seasons, we could see spatial resemblance in phytoplankton group composition, where Px-N and Px-S were similar in the warm seasons (spring and summer). 

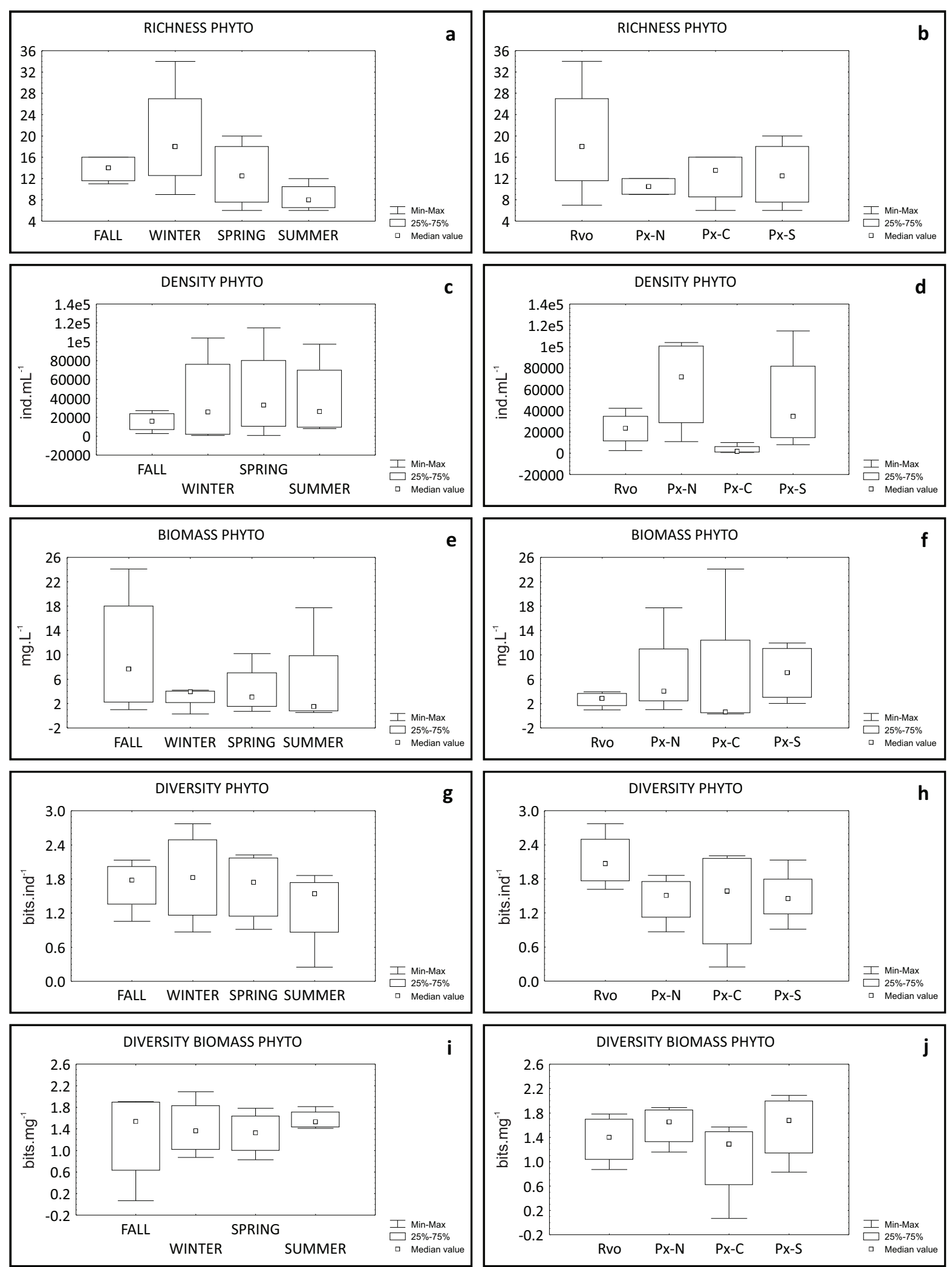

Figure 4 - Structure of phytoplankton communities in the Ruivo and Peixe lagoons with regard to seasonal (left) and spatial (right) distribution. (Legend for locations see Table I) 
However, in the winter samples, Px-N was more similar to Px-C, composed by diatoms, clorophytes and cyanobateria. The Chroococcus spp. $(83,844$ ind. $\left.\mathrm{mL}^{-1}\right)$ and the diatom Chaetoceros sp. $(33,291$ ind. $\mathrm{mL}^{-1}$ ) were dominant in this season at Px-N and $\mathrm{Px}-\mathrm{S}$, respectively. $\mathrm{Px}-\mathrm{N}$ and $\mathrm{Px}-\mathrm{S}$ were dominated by cyanobacteria in spring, indicated by the correlation with chlorophyll $a$ - blue (0.78) and chlorophyll $a$ - green (0.86), Chroococcus spp. $\left(85,302\right.$ ind. $\left.\mathrm{mL}^{-1}\right)$ became dominant at Px-S. In summer samples, cryptophytes (Hemiselmis sp.) and dinophyceae were the most abundant groups at Px-N and Px-S, and correlated with chlorophyll $a$ - brown (0.50) for cryptophytes and (0.52), for dinophyceae. Diatoms were the most abundant group at $\mathrm{Px}-\mathrm{C}$, in spring samples Asterionellopsis glacialis (Castracane) Round and Nitzschia sp. 12 $\left(9,514\right.$ ind. $\left.\mathrm{mL}^{-1}\right)$ were dominant in summer samples.
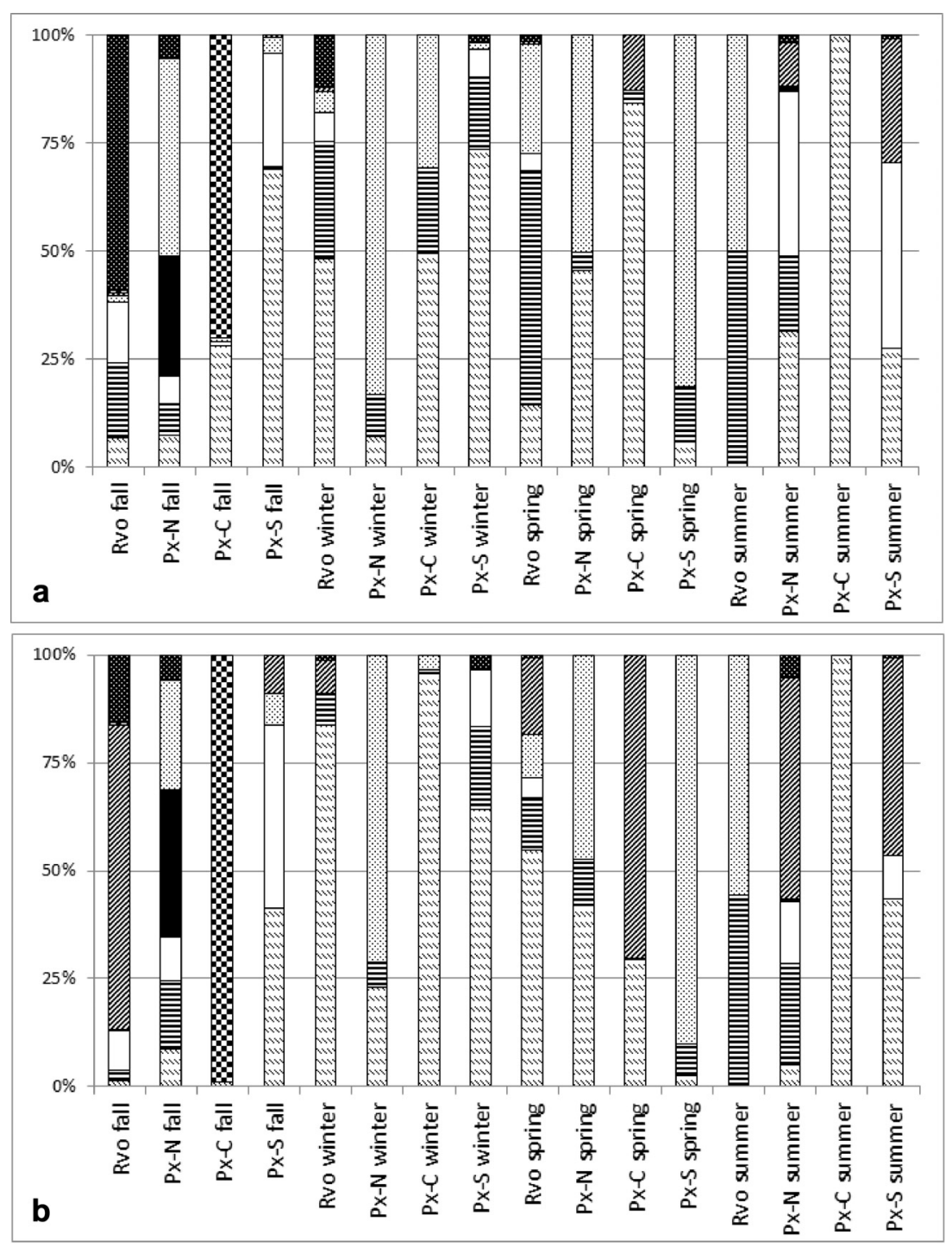

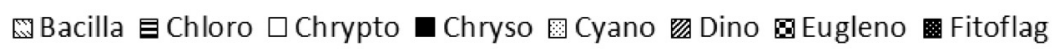

Figure 5 - Relative contribution (\%) of density (a) and biomass (b) of phytoplankton groups in the Ruivo and Peixe lagoons. (Legend for locations see Table I) 
The relative contribution of phytoplankton groups to biomass was similar to density, with some exceptions (Fig. 5b). The most abundant groups were Euglenophyceae and Bacillariophyceae, but Dinophyceae also played an important role. Again, fall was the most heterogeneous season, but only at Px-C Euglena sp. (23.86 mg. $\left.\mathrm{L}^{-1}\right)$ remained dominant. Durinskia sp. $\left(2.42 \mathrm{mg} . \mathrm{L}^{-1}\right)$ was the dominant species at Rvo. In winter samples, the biomass pattern of the groups was the same as for density, with Chroococcus spp. (2.92 mg. $\left.\mathrm{L}^{-1}\right)$ remaining dominant at $\mathrm{Px}-\mathrm{N}$, whereas for $\mathrm{Px}-\mathrm{C}$ and Rvo sites the dominance was replaced by larger diatom species, such as Diploneis didyma Ehrenberg (Ehrenberg) (0.17 mg. $\left.\mathrm{L}^{-1}\right)$ and Surirella sp. 2 (3.19 mg. $\left.\mathrm{L}^{-1}\right)$, respectively. In spring samples, Chroococcus spp. (7.78 mg. $\left.\mathrm{L}^{-1}\right)$ remained dominant at Px-N, correlating with chlorophyll $a$ - blue (0.97) and green (0.74). In summer samples, the dominance of dinoflagellates at Px-N and Px-S kept these points more similar. Asterionellopsis glacialis was the only species recorded at $\mathrm{Px}-\mathrm{C}$ in samples from all seasons, and its biomass was correlated with conductivity $(0.51)$ and salinity $(0.54)$.

The Canonical Correspondence Analysis (CCA) relating between the biomass of abundant species ( $\mathrm{n}=15 \mathrm{spp}$.), chlorophyll $a$, and the physical and chemical variables explained $50.1 \%(p=0.02)$ of the variability on the first two axes (Fig. 6). On the negative side of axis 1 , high values of salinity,

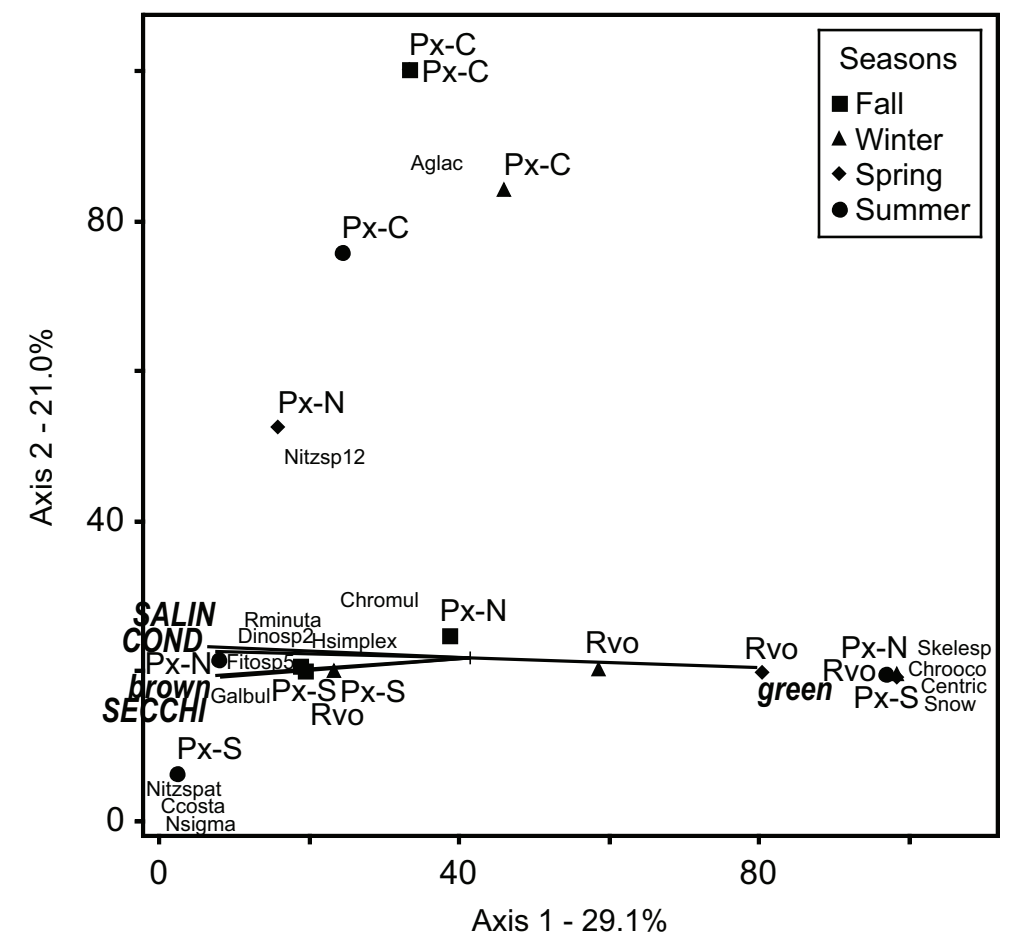

Figure 6 - Canonical Correspondence Analysis (CCA) Ordination plot for seasonal phytoplankton biomass of recorded taxa in the Ruivo and Peixe lagoons. (Legend for locations and variables see Table I; Aglac Asterionellopsis glacialis, Nitzsp12 - Nitzschia sp. 12, Dinosp2 - Dinoflagellate sp.2, Chromul - Chromulina sp., Rminuta - Rhodomonas minuta var. nannoplanctonica, Phytosp5 - Phytoflagellate sp.5, Hsimplex - Hemiselmis simplex, Galbul - Gymnodinium albulum, Nsigma - Nitzschia cf. sigmaformis, Ccosta - Chaetoceros cf. costatus, Nitzspat - Nitzschia spathulata, Skelesp Skeletonema sp., Chrooco - Chroococcus spp., Centric - Centric diatom, Snow - Snowella spp.) 
conductivity, chlorophyll $a$ - brown, and Secchi transparency separated fall from the other seasons, however, the samples from $\mathrm{Px}-\mathrm{C}$ were grouped by having their environment more influenced by the input of seawater through the channel. This marine influence was indicated by Asterionellopsis glacialis, a marine diatom that causes frequent blooms in the sea of southern Brazil. On the other hand, changes of phytoplankton community in response to a salinity decrease generated a seasonal gradient at Px-S and Rvo, when cyanobacteria (Chroococcus spp.) were found.

\section{ZOOPLANKTON}

The zooplankton of both lagoons was composed of 57 taxa of the groups Rotifera (27), Protista (15), Copepoda (5), Cladocera (1) and others (different larval stages, icthyoplankton, foraminifera, i.e., marine organisms) (9).

The spatial pattern of zooplankton richness was similar to phytoplankton, also higher at Rvo, but with a distinct seasonal gradient increasing from fall to spring (Figs. $7 \mathrm{a}$ and $7 \mathrm{~b}$ ). The decrease in specific richness in summer samples and at $\mathrm{Px}-\mathrm{C}$ was negatively related to the inflow of saline water, reflected by negative correlations of specific richness with conductivity (-0.79) and salinity $(-0.77)$.

Zooplankton density ranged from 6,000 to $2,966,000$ ind. $\mathrm{m}^{-3}$. Density was in general uniformly distributed among the seasons (Fig. 7c) with exception of winter samples. Spatially, the lowest densities were recorded at Px-C (Fig. 7d), as well as for phytoplankton, but zooplankton density was significantly correlated with TP $(0.50)$ and chlorophyll $a$ - green (0.59), with peaks at Px-N in winter.

The specific diversity was higher in spring (2.0 bits.cel $^{-1}$ ) (Fig. 7e) whereas spatial diversity was higher at Rvo (1.8 bits.cel $^{-1}$ ) (Fig. 7f), as well as for phytoplankton diversity according to density.
There was a negative correlation between diversity and TN (-0.52), mainly due to the decrease of this nutrient in spring.

Concerning density, Protista and Rotifera were the most abundant groups (Fig. 8), but with particular seasonal and spatial distribution. In fall, zooplankton composition at Px-N and Px-C was similar, consisting mainly of representatives of the group others followed by Copepoda. The Rotifera group was resident only in extreme sites of system (Rvo and Px-S) during fall and winter. In winter, Protista dominated the zooplankton and in spring, Rotifera became the most abundant group. In summer, Copepoda has become an important, except at Rvo where Rotifera remained dominant.

ORDINATION ANALYSIS OF THE PHYTO- AND

ZOOPLANKTON AND THE ENVIRONMENT

The first two axes of the Redundancy Analysis (RDA) explained $45.9 \%(p=0.01)$ of the variation in the density of plankton groups (Fig. 9). Axis 1 separated the samples associated with Secchi depth and chlorophyll $a$ - brown from those associated with chlorophyll $a$-green, chlorophyll $a$-blue and TP. On this axis, Px-S showed a seasonal separation mainly related to chlorophyll $a$. In fall, winter and summer, the community at Px-S consisted mostly of diatoms and cryptophytes, evidenced by the high values of chlorophyll $a$ - brown in these samples. However, in spring the community consisted mainly of cyanobacteria, indicated by its close proximity to the vector representing chlorophyll $a$ - blue.

The high values of salinity and conductivity on the negative side of axis 2 were responsible for the seasonal gradient at $\mathrm{Px}-\mathrm{C}$, and also led to its divergence from the other sites during the summer, when salinity in the Peixe lagoon was higher (Table I). Euglenoids were dominant with regard to density at Px-C in fall. The zooplankton group referred to as "other" (larval stages and marine zooplankton) was more strongly related to salinity, 

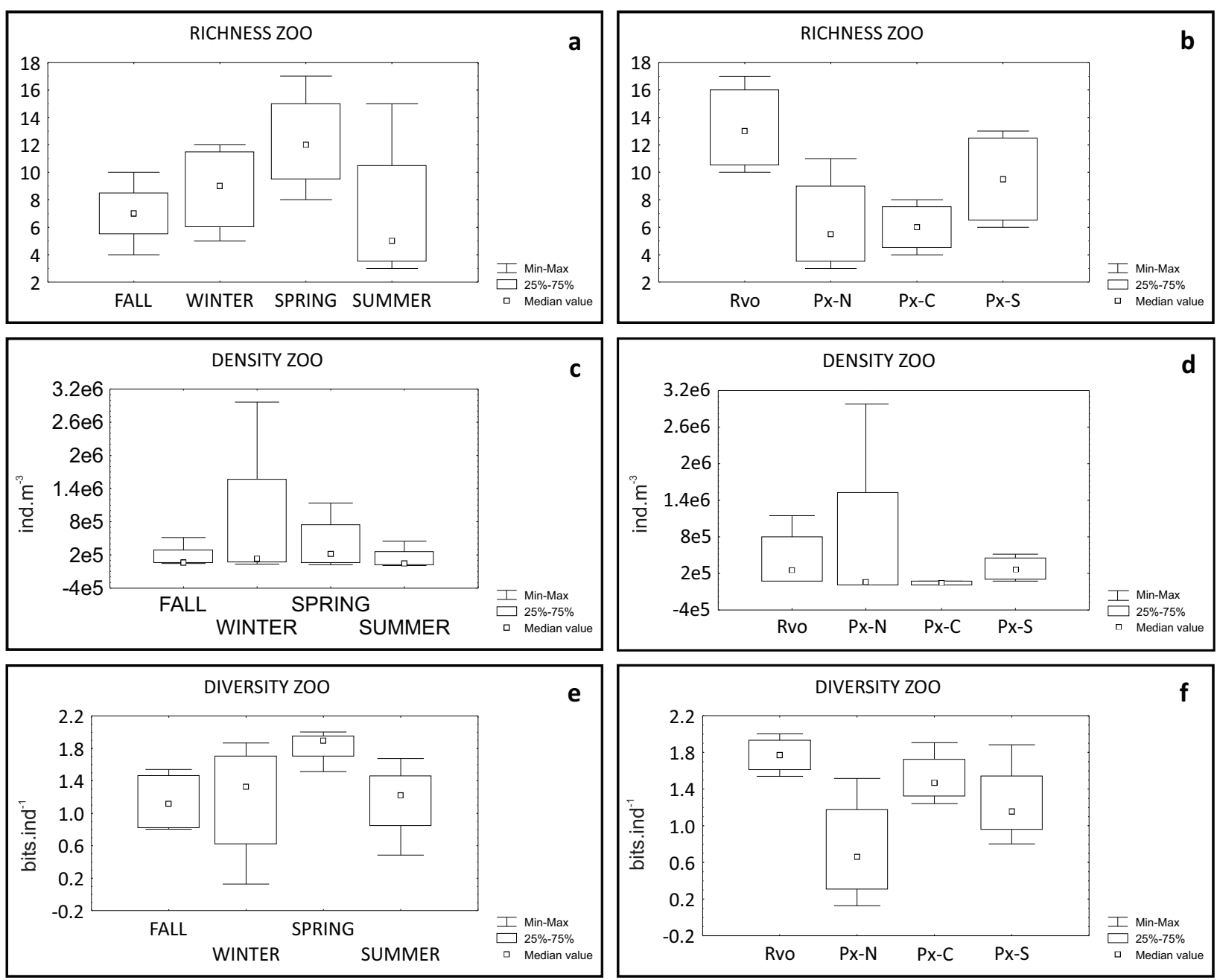

Figure 7 - Structure of the zooplankton community in the Ruivo and Peixe lagoons at seasonal (left) and spatial (right) scales. (Legend for locations see Table 1)

emphasizing the effect of seawater intrusion on the plankton community composition. Salinity and conductivity in Px-N was noticeably seasonal with fall and summer samples associated to these vectors. Summer samples were additionally associated with lower values of DO and with dinoflagellates (Px-N and $\mathrm{Px}-\mathrm{S})$.

\section{DISCUSSION}

The Peixe and Ruivo lagoons are dynamic systems strongly influenced by salinity fluctuations due to precipitation and evaporation in the area, freshwater inflow from the adjacent wetland and farms, and seawater introduction through removal of the sand bar that divides the lagoon from the ocean. The two last factors are heavily influenced by winds.

The Peixe lagoon was more saline in summer, which is to be expected in these shallow systems due to higher temperature and evaporation. Ruivo lagoon was most saline during fall, probably due to occlusion of the channel and lower precipitation. Low salinity in winter resulted from larger precipitation, but also from the recent opening of the channel, which drained water from the lagoon to the sea. Previous studies in the Peixe lagoon (Crippa et al. 2013, Rolon et al. 2013) did not report the same variation of salinity observed here, despite the temporary closing of the channel. However, 


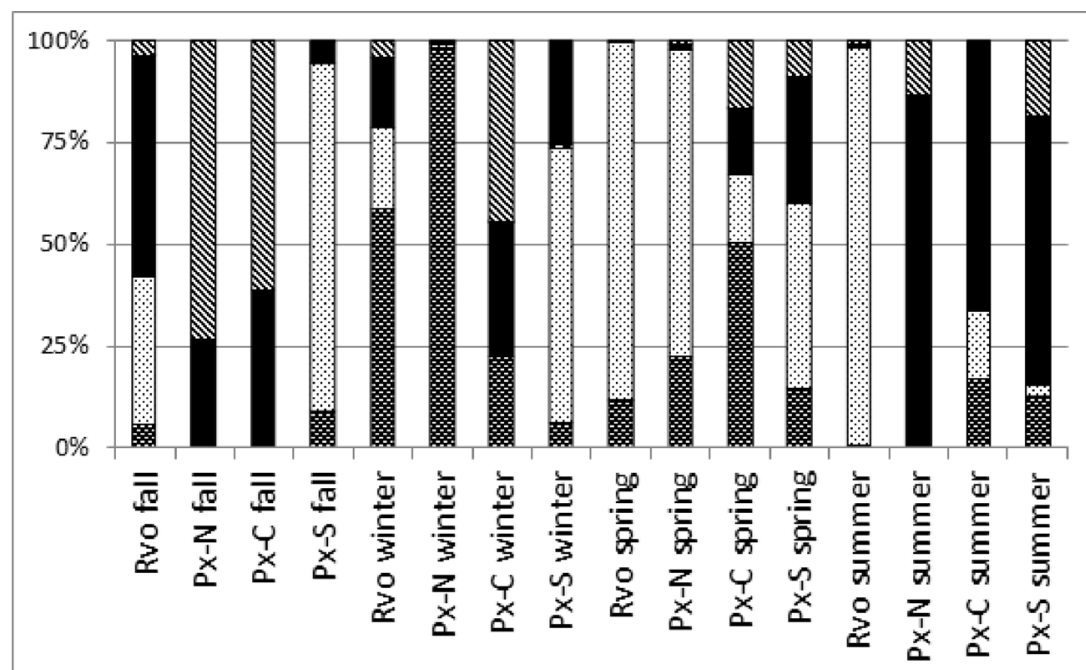

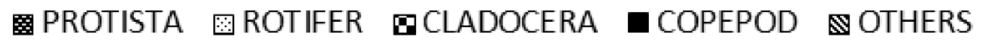

Figure 8 - Relative contribution (\%) of density of zooplankton groups in the Ruivo and Peixe lagoons at all sampling dates. (Legend for locations see Table I)

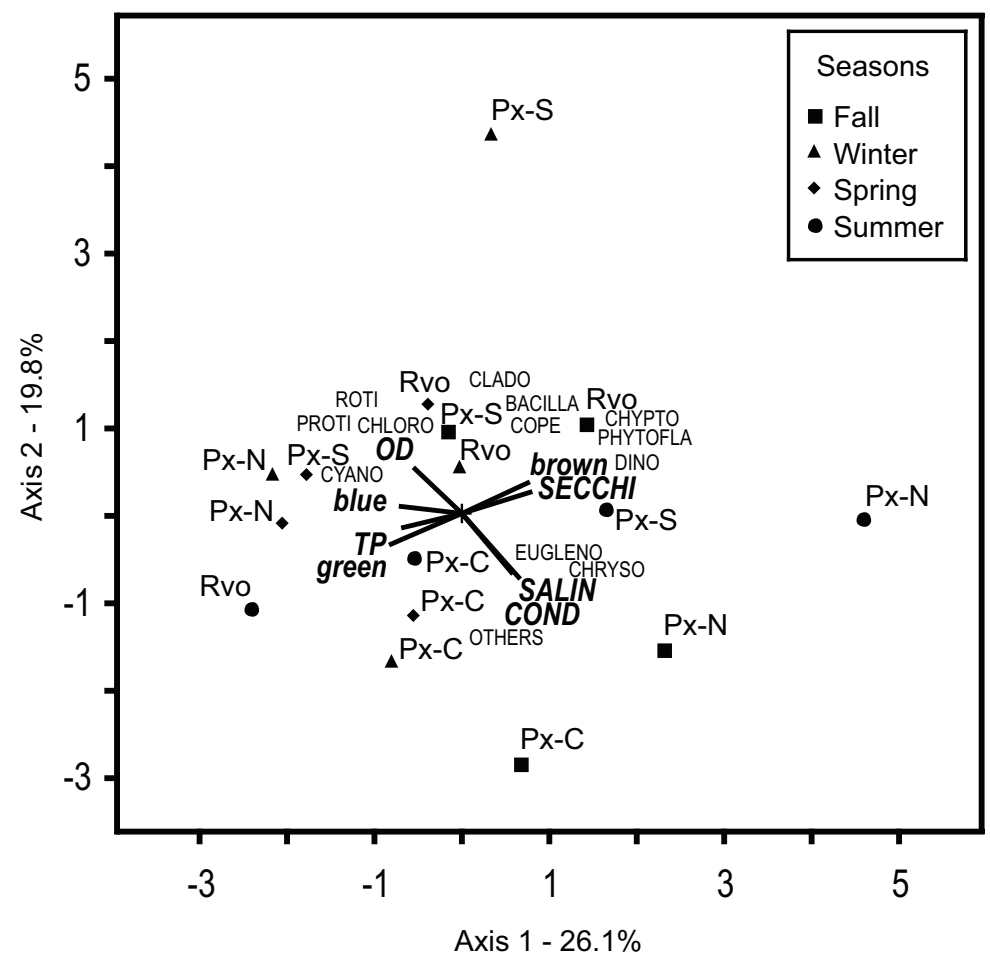

Figure 9 - Redundancy Analysis (RDA) Ordination plot of seasonal density of planktonic groups in the Ruivo and Peixe lagoons (Legend for locations and variables see Table I; BACILLA = Bacillariophyceae, CHLORO = Chlorophyceae, CRYPTO = Cryptophyceae, CHRYSO = Chrysophyceae, CYANO = Cyanophyceae, DINO = Dinophyceae, EUGLENO = Euglenophyceae, PHYTOFLA $=$ Phytoflagellates, PROTI $=$ Protista, ROTI $=$ Rotifera, $\mathrm{CLADO}=$ Cladocera, $\mathrm{COPE}=$ Copepoda, $\mathrm{OTHERS}=$ refers to larval stages and other marine zooplankton groups such as foraminifera). 
Truccolo (1993) observed similar salinity, as we found, with lower values during winter and higher in summer. Inter-annual variability of the salinity has been common in the coastal lagoon from South of Brazil, as observed in Patos lagoon estuary (Abreu et al. 2010) and Tramandaí-Armazém lagoons (Callegaro et al 1981), and this variation has relation with the rainfall levels in the region that are strongly influenced by the El Niño Southern Oscillation.

Phytoplankton community structure responds strongly to abiotic variables, according to their ecological preferences (Bellinger and Sigee 2010, Reynolds 1984). Diatoms often predominate in areas with high salinity, low temperature and high silica concentration and turbulence (Armi et al. 2010, Ramdani et al. 2009). A remarkable presence of Asterionellopsis glacialis, a cosmopolitan marine diatom species frequently found on the southern coast of Brazil and the coast of Argentina, was recorded at Px-C. At this site, salinity remained high due to the channel opening, maintaining communication with the ocean throughout most of the study period. High abundances of this species can be found off the coast of Rio Grande do Sul throughout the year (Odebrecht et al. 1995, 2010b, Rörig and Garcia 2003). For example, during the summer of 2012 a remarkable bloom was reported by the local press (Cardoso 2012).

Dinoflagellates were more diverse in summer, due to higher salinity, as observed by Fujita and Odebrecht (2007) and lower wind velocity, probably because of their preference for lowturbulence waters (Wong et al. 2007). We did not record the presence of harmful Dinoflagellates as observed in the Patos lagoon estuary (Fujita and Odebrecht 2007). The richness of this group was higher (Fujita and Odebrecht 2007) probably due to a deeper system, which allowed them to explore more effectively the resources in the water column.

The high biomass of the benthic diatom Diploneis didyma and Surirella sp. 2 coinciding with the highest mean wind velocity (winter and spring) may be attributable to sediment suspension (Wong et al. 2007). The highest phytoplankton richness, specific diversity and silicate value observed in winter, probably resulted from this suspension. The presence of benthic microalgae in the plankton was also observed in other shallow lakes (Cardoso and Motta Marques 2003, 2004a, Colak Sabanci 2014, Bergesch et al. 1995, Bonilla et al. 2005, Brito 2012, Ramdani et al. 2009, Padisák 1993).

In the Peixe lagoon, the lowest specific richness values in summer were associated with highest salinity. On the other hand, the highest specific richness at Ruivo lagoon can be explained mainly by the presence of a large number of freshwater species related to low salinity in this water body, which receives water from a wetland with an extensive macrophyte bank. Similar conditions were reported by Ramdani et al. (2009) and Kruk et al. (2009) for subtropical shallow lakes.

Cyanobacteria had the highest density, followed by diatoms, these groups were also the most important in the Tramandaí-Armazém lagoons (Callegaro et al. 1981) and Patos lagoon (Torgan 1997), except for the Patos lagoon estuary, where Nanoflagellates overlapped to these groups (Fujita and Odebrecht 2007). In other coastal lagoons with similar salinity level, diatoms and dinoflagellates are usually the main phytoplankton components (Acri et al. 2004, Armi et al. 2010, Bonilla et al. 2005, Colak Sabanci 2014, Fanuko and Valčić 2009, Melo and Suzuki 1998, Ramdani et al. 2009, Varona-Cordero et al. 2010). Euglenoids presented the highest biomass, which is also unusual compared to other lagoonal system (Bonilla et al. 2005). Diatoms predominated in terms of specific richness, and seem to have the ability to attain relevant density at a wide range of salinity, but with a transition between freshwaters and marine species, as observed by Hamilton et al. (2000). The most representative genus in number of 
species was Nitzschia, as observed in the Moroccan lagoon Merja Zerga (Ramdani et al. 2009).

In several temperate lagoons, seasonal distribution of phytoplankton groups was more strongly correlated with temperature than with salinity (Armi et al. 2010, Pachés et al. 2014). Our results resembled those of Melo et al. (2007) for the tropical zone, where fluctuations in salinity and nutrient availability were the main drivers of phytoplankton community structure. The Mexican tropical lagoons resemble the Peixe lagoon with respect to community dynamics. Distribution, composition and abundance of the algal community were influenced, both spatially and seasonally, by salinity and DO (Varona-Cordero et al. 2010).

Phytoplankton density in the Peixe lagoon was similar to the tropical lagoon of Imboassica in Rio de Janeiro, which showed a maximum value of 70,000 cel. $\mathrm{mL}^{-1}$ (Melo and Suzuki 1998). However, density in the Peixe lagoon was higher than in other subtropical lagoons in South America (Callegaro et al. 1981, Conde et al. 2003, Torgan 1997). Abundance and dominance of taxa differed when obtained from either biomass or density due to the high number of small cells (e.g. Chlorophyceae), or low number of large cells (e.g. Dinoflagellates). This is exemplified by our observations at Px-C, density and biomass were the lowest, except in fall, when a high biomass value $\left(24.1 \mathrm{mg} . \mathrm{L}^{-1}\right)$ was recorded despite low density $\left(2,689\right.$ ind. $\left.\mathrm{mL}^{-1}\right)$. At this time, the dominant taxon was Euglena sp., which has a high cell volume. According to Bonilla et al. (2005), the connection between the lagoon and the sea regulates phytoplankton biomass. The flow of the water from the lagoon to the sea prevents eutrophication, and possibly caused lower density at Px-C, and reduced biomass in winter, after the opening of the channel. The large size of zooplankton (e.g. of several larval stages, ichthyoplankton, etc.) may have exerted a topdown control on phytoplankton at $\mathrm{Px}-\mathrm{C}$, while at the other sampling sites, microzooplankton was more prevalent than macrozooplankton. Predators, such as planktivorous fish and macroinvertebrates, are an important factor in brackish systems. Their presence is related to the salinity gradient and also highly affected by temperature. Hence, a rise in temperature will increase predation pressure on the zooplankton community, modifying its composition and diversity (Anton-Pardo and Armengol 2012) with a cascade effect on phytoplankton and bacterioplankton.

Regarding zooplankton community structure, the largest number of species in spring, the higher specific richness of rotifers and the abundance of protists and rotifers agree with observations in the Tramandaí lagoon, another subtropical system that has a permanent connection to the sea (Cardoso and Motta Marques 2006). Seasonally, an increasing gradient of specific richness from fall to spring was also reported. However, the relationship between specific richness and salinity differed from our system: in the Tramandaí lagoon, specific richness was the greatest at a higher salinity, while we observed the greatest specific richness in the Ruivo lagoon, where salinity was lower.

A survey of existing studies in inland saline waters (listed by Horváth et al. 2013) showed that zooplankton diversity and specific richness generally decline with salinity. Rotifera was the only group that decreased in density with increasing conductivity, but this relationship was not significant (Horváth et al. 2013). However, in the Peixe lagoon, density of Rotifera was negatively correlated to conductivity $(-0.51)$, as was total specific richness of zooplankton (-0.79). Salinity is known as a strong determinant of aquatic communities in brackish systems (lagoons, estuaries), causing the death of species that cannot tolerate the increase of salt concentration. Some studies that focused on this variable (Anton-Pardo and Armengol 2012) showed that a rise in salinity leads to a decrease in species richness and diversity in the zooplankton community. This causes important shifts: the 
dominance of large-sized cladocerans at low salinities is replaced by the dominance of copepods (mainly calanoids) at high salinities (Anton-Pardo and Armengol 2012). Indeed, copepods (mainly juvenile instars of Acartia tonsa) were dominant in the Peixe lagoon in summer, when salinity was high. However, cladocerans (Chydorus sphaericus) never dominated the community at low salinities, while rotifers and protists did. Acartia tonsa dominated the zooplankton community in areas with saltwater intrusion, such as the central basin of Vistula lagoon (Paturej et al. 2012) and the estuary of Patos lagoon (Muxagata et al. 2012).

Horizontal flow of water (exchange with adjacent systems) is the predominant factor governing plankton in lakes and coastal lagoons, and is even more intense in estuaries (Margalef 1983). The process of water circulation in estuaries disfavors the formation of spatiality in these environments, while seasonality plays a more important role in distribution patterns and composition. In contrast to this, the morphology of lagoonal systems provides less circulation with adjacent systems, allowing some planktonic communities to be more stable. According to Bonilla et al. (2005), the phytoplankton community of Rocha lagoon primarily reflects the hydrological state, and secondarily, the nutrient status of the environment. Permanent mixing of the water column, sediment resuspension, and bidirectional horizontal flow are physical conditions that impact the species presence. The seasonal variations observed in our study were characteristic of subtropical weather, associated for example with rainfall or cold fronts (Fontes and Abreu 2012, Hennemann and Petrucio 2011). The spatial and seasonal changes of the plankton community in the Peixe and Ruivo lagoons were strongly influenced by the channel opening which allowed the exchange of continental and coastal water, changing salinity. In addition, the wind action besides promoting the entry of ocean water permitted the inflow of dissolved oxygen into the water as well as resuspended sediment. High precipitation in winter was also an important factor for the variations in salinity in the lagoons. Further studies in short- and long-term would give us more accurate information into the plankton community dynamics.

\section{ACKNOWLEDGMENTS}

We thank the Conselho Nacional de Desenvolvimento Científico e Tecnológico - Programa de Capacitação em Taxonomia (CNPq - PROTAX) for the resources granted to the project. We also thank the Centro de Ecologia do Instituto de Biociências da Universidade Federal do Rio Grande do Sul, the chemist Manoel Luiz Nunes from the Museu de Ciências Naturais da Fundação Zoobotânica do Rio Grande do Sul for performing the chemical analysis as well as the Instituto de Pesquisas Hidráulicas (IPH) - Universidade Federal do Rio Grande do Sul for making PHYTO-PAM available for analysis of the chlorophyll $a$. The authors acknowledge the Instituto Chico Mendes de Conservação da Biodiversidade (ICMBio) for support in field expeditions. We thank Dr. H.D. Laughinghouse IV and R.M. Fischer for reviewing the English text.

\section{RESUMO}

As variações da comunidade planctônica em um sistema lagunar raso subtropical e sua relação com as condições ambientais foram investigadas durante um ciclo anual, a fim de fornecer informações sobre o seu padrão de variação espacial e sazonal. O estudo foi realizado em quatro locais, três na Lagoa do Peixe e um na Lagoa do Ruivo, localizados no Parque Nacional da Lagoa do Peixe, sul do Brasil. O sistema comunica-se temporariamente com o Oceano Atlântico por um estreito canal. A densidade fitoplanctônica foi mais elevada na Lagoa do Peixe, enquanto que a maior riqueza específica ocorreu na Lagoa do Ruivo, local que apresentou menor salinidade. A biomassa fitoplanctônica próximo ao canal apresentou variação sazonal, com valor mais elevado no outono e menor no inverno. A riqueza do zooplâncton foi inversamente correlacionada com a salinidade, tendo valores mais elevados na Lagoa do Ruivo. A análise 
de ordenação indicou padrões sazonais e espaciais na comunidade planctônica deste sistema lagunar, relacionados com a variação da salinidade. Além disso, a ação do vento e a precipitação foram fatores importantes para as mudanças espaciais e sazonais de salinidade na lagoa, com influência direta na dinâmica da comunidade planctônica.

Palavras-chave: laguna costeira, microalgas, sítio Ramsar, sul do Brasil.

\section{REFERENCES}

ABREu PC, BERGESCH M, PROENÇA LA, GARCiA CAE AND ODEBRECHT C. 2010. Short- and long-term chlorophyll $a$ variability in the shallow microtidal Patos Lagoon estuary, Southern Brazil. Estuar Coast 33: 554-569.

ACRI F, AUBRY FB, BERTON A, BIANCHI F, BOLDRIN A, CAMATTI E, COMASCHI A, RABITTI S AND SOCAL G. 2004. Plankton communities and nutrients in the Venice Lagoon. Comparison between current and old data. J Marine Syst 51: 321-329.

ANONYMOUS. 1959. Final resolution. Symposium on the Classification of Brackish Waters, Venezia 8-14 Aprile, 1958. Arch Oceanogr Limnol, Suppl 11: 243-245.

ANTON-PARDO M AND ARMENGOL X. 2012. Effects of salinity and water temporality on zooplankton community in coastal Mediterranean ponds. Estuar Coast Shelf S 114: 93-99.

APHA - AMERicAn Public Health Association. 1998. Standard Methods for Examination of Water and Wastewater. $20^{\text {th }}$ ed., Washington, DC.

ARMi Z, TRABELSI E, TURKI S, BÉJAOUI B AND MAÏZ NB. 2010. Seasonal phytoplankton responses to environmental factors in a shallow Mediterranean lagoon. J Mar Sci Technol 15: 417-426.

Bellinger EG AND SigeE DC. 2010. Freshwater Algae: identification and use as bioindicators. Chichester: J Wiley \& Sons, $271 \mathrm{p}$.

BERGESCH M AND ODEBRECHT C. 1987. Variações sazonais da biomassa do fitoplâncton total e fracionada em categorias de tamanho, em área estuarina rasa da Lagoa dos Patos, RS. Simpósio Sobre Ecossistemas da Costa Sul e Sudeste Brasileira. São Paulo: Aciesp, p. 290-296.

Bergesch M, Odebrecht C AND ABreu PC. 1995. Microalgas do estuário da Lagoa dos Patos: interação entre o sedimento e a coluna de água. Oecol Bras 1: 273-289.

Bonilla S, CONDE D, Aubriot L AND PÉRES MC. 2005. Influence of hydrology on phytoplankton species composition and life strategies in a subtropical coastal lagoon periodically connected with the Atlantic Ocean. Estuaries 28(6): 884-895.

BRITO AC, FERNANDES TF, NEWTON A, FACCA C AND TEFF P. 2012. Does microphytobenthos resuspension influence phytoplankton in shallow systems? A comparison through a Fourier series analysis. Estuar Coast Shelf S 110: 77-84.

CALlegaro VLM, Rosa ZM AND WERnER VR. 1981. Comunidades fitoplanctônicas das Lagoas de Tramandaí e do Armazém, Tramandaí. Iheringia Ser Bot 28: 3-16.

CARDOSO LS. 2012. O dia mais quente do verão em Capão. Zero Hora. Porto Alegre, p. 32.

CARdoso LS AND MotTA MARques D. 2003. Rate of change of the phytoplankton community at Itapeva Lake (North Coast of Rio Grande do Sul, Brazil), based on the wind driven hydrodynamic regime. Hydrobiologia 497: $1-12$.

CARdoso LS AND MotTA MARQues D. 2004a. Seasonal composition of the phytoplankton community in Itapeva lake (north coast of Rio Grande do Sul-Brazil) in function of hydrodynamic aspects. Acta Linmol Bras 16(4): 401416.

CARdoso LS AND MotTA MARQueS D. 2004b. Structure of the zooplankton community in a subtropical shallow lake (Itapeva Lake - South of Brazil) and its relationship to hydrodynamic aspects. Hydrobiologia 518: 123-134.

CARDOSO LS AND MOTTA MARQUES D. 2006. Relações do índice de qualidade de água (IQA) com a variação temporal e espacial da comunidade zooplanctônica do sistema lagunar de Tramandaí (Litoral Norte do Rio Grande do Sul - RS Brasil). Rev Bras Rec Hid 11(2): 123-134.

CARDoso LS AND MotTA MARQUeS D. 2009. Hydrodynamics-driven plankton community in a shallow lake. Aquat Ecol 43: 73-84.

Chapman BR, FERry BW AND FORD TW. 1998. Phytoplankton communities in water bodies at Dungeness, U.K.: analysis of seasonal changes in response to environmental factors. Hydrobiologia 362: 161-170.

COLAK SABANCI F. 2014. Phytoplankton distribution and its relationship to the physico-chemical environment in a coastal lagoon. Ekoloji 23(90): 61-72.

CONDE D, RODRÍGUEZ-GALLEGO L AND RODRÍGUESGRAÑA L. 2003. Análisis conceptual de las interacciones abióticas y biológicas entre el océano y las lagunas de la costa atlántica de Uruguay. PNUD/GEF/RLA/99/ G31 (FREPLATA-Ciencias 8). Sección Limnología, FC/ UDELAR, $65 \mathrm{p}$.

CONDE D AND SOMMARUGA R. 1999. A review of the state of limnology in Uruguay. In: Wetzel RG and Gopal B (Eds), Limnology in developing countries. New Delhi: SIL/ International Science Publishers, p. 1-31.

COSTA CS AND TAGLIANI PR. 2011. Cobertura vegetal e uso preponderante do espaço. In: Tagliani PRA (Ed), Ecologia da paisagem da restinga da Lagoa dos Patos: uma contribuição para o manejo e conservação da Reserva da Biosfera. Rio Grande: Editora da Furg, 184 p.

CRIPPA LB, Stenert C AND MALTChIK L. 2013. Does the management of sandbar openings influence the macro- 
invertebrate communities in southern Brazil wetlands? A case study at Lagoa do Peixe National Park - Ramsar site. Ocean Coast Manage 7: 26-32.

Crossetti LO, Becker V, CARdoso LS, Rodrigues LR, Costa LS AND MotTA-MARQues D. 2012. Is phytoplankton functional classification a suitable tool to investigate spatial heterogeneity in a subtropical shallow lake? Limnologia 43(3): 157-163.

FANUKO N AND VALČIĆ M. 2009. Phytoplankton composition and biomass of the northern Adriatic lagoon of Stella Maris, Croatia. Acta Bot Croat 68(1): 29-44.

FONTES ML AND ABREU PC. 2012. A vigorous specialized microbial food web in the suboxic waters of a shallow subtropical coastal lagoon. Microbial Ecol 64: 334-345.

FUJITA CC AND ODEBRECHT C. 2007. Short term variability of chlorophyll $a$ and phytoplankton composition in a shallow area of the Patos Lagoon estuary (Southern Brazil). Atlântica 29(2): 93-1006.

GAmeiro C, CARTAXANA P AND BRotas V. 2007. Environmental drivers of phytoplankton distribution and composition in Tagus Estuary, Portugal. Estuar Coast Shelf S 75: 21-34.

HAMILTON DP, CHAN TU, ROBSON BJ AND HODGES BR. 2000. The effects of freshwater flows and salinity on phytoplankton biomass and composition in an urban estuary, the Swan River, Western Australia. Proceeding of Hydro 2000 Conference, $26^{\text {th }}$ National and $3^{\text {rd }}$ International Hydrology and Water Resource Symposium (IEAust). ed./Scientific Committee. Vol. 1 Perth. ed., Barton, ACT: Institution of Engineers, Australia, p. 114-119.

Hennemann MC AND PETRUCiO MM. 2011. Spatial and temporal dynamics of trophic relevant parameters in a subtropical coastal lagoon in Brazil. Environ Monit Assess 181: 347-361.

HiLlebrand H, DÜRSELEN C, KIRSCHTEl D, POLLINGHER U AND ZOHARY T. 1999. Biovolume calculation for pelagic and benthic microalgae. J Phycol 35: 403-424.

HORVÁTH Z, VAD CF, VÖRÖS L AND BOROS E. 2013. The keystone role of anostracans and copepods in European soda pans during the spring migration of waterbirds. Freshwater Biol 58: 430-440.

KJERFVE B. 1994. Coastal lagoons. In: Kjerfve B (Ed), Coastal lagoon processes. Amsterdam: Elsevier Oceanography Series, p. 1-8.

KNAK RB (Org). 1999. Plano de Manejo do Parque Nacional da Lagoa do Peixe. IBAMA FNMA/FURG/NEMA/ UFPEL, Brasília, Brasil, 465 p.

Kruk C, RodrígueZ-Gallego L, Meerhoff M, QuintANS F, LACEROT G, MAZZEO N, SCASSO F, PAGGI JC, PEETERS ETHM AND MARTEN S. 2009. Determinants of biodiversity in subtropical shallow lakes (Atlantic coast, Uruguay). Freshwater Biol 54: 2628-2641.

LOBO EA AND LEIGHTON G. 1986. Estructuras comunitarias de las fitocenosis planctónicas de los sistemas de desembocaduras de ríos y esteros de la zona Central de Chile. Rev Biol Mar 22(1): 1-29.

LOEBMANN D AND VIEIRA JP. 2006. O impacto da pesca do camarão-rosa Farfantepenaeus paulensis (Perez-Farfante) (Decapoda, Penaeidae) nas assembléias de peixes e siris do Parque Nacional da Lagoa do Peixe, Rio Grande do Sul, Brasil. Rev Bras Zool 23(4): 1016-1028.

MARGALEF R. 1983. Limnología. Barcelona: Omega, 1010 p.

MATOS JB, SOdRÉ DKL, DA COSTA KG, PEREIRA LCC AND DA COSTA RM. 2011. Spatial and temporal variation in the composition and biomass of phytoplankton in an Amazonian estuary. J Coastal Res SI 64: 1525-1529.

MCCUNE B AND MEFFORD MJ. 2011. PC-ORD. Multivariate Analysis of Ecological Data. Version 6.08 MjM Software, Gleneden Beach, Oregon, U.S.A.

MELO S, BOZELLI RL AND ESTEVES FA. 2007. Temporal and spatial fluctuations of phytoplankton in a tropical coastal lagoon, southeast Brazil. Braz J Biol 67(3): 475-483.

MELO S AND SUZUKI MS. 1998. Variações temporais e espaciais do fitoplâncton das Lagoas Imboassica, Cabiúnas e Comprida. In: Esteves FA (Ed), Ecologia das Lagoas Costeiras do Parque Nacional da Restinga de Jurubatiba e do Município de Macaé. Núcleo de Pesquisas Ecológicas de Macaé (NUPEM) - Rio de Janeiro: Universidade Federal do Rio de Janeiro, p. 177-203.

MOREIRA-FILHO H AND VALENTE-MOREIRA IM. 1981. Avaliação taxonômica e ecológica das diatomáceas (Bacillariophyceae) epífitas em algas pluricelulares obtidas nos litorais dos Estados do Paraná, Santa Catarina e São Paulo. Bol Mus Bot Mun 47: 1-17.

MULlER OO, PAIM PSG AND SOARES ID. 1991. Facteurs et mecanismes de la circulation des eaux dans l'estuaire de la lagune dos Patos (RS, Bresil). Bull Inst Geol Bassin Aquitaine 49: 15-21.

MuXagata E, AMARAL WJA AND BARbosa CN. 2012. Acartia tonsa production in the Patos Lagoon estuary, Brazil. ICES J Mar Sci 69(3): 475-482.

ODEBRECHT C AND ABREU PC. 1998. Microalgas. In: Seelinger U, Odebrecht $\mathrm{C}$ and Castello JP (Eds), Os ecossistemas costeiro e marinho do extreme sul do Brasil. Rio Grande: Ecoscientia, p. 36-42.

ODEBRECHT C, ABREU PC, MÖLLER JR OO, NIENCHESKI LF, PROENÇA LA AND TORGAN LC. 2005. Drought effects on pelagic properties in the shallow and turbid Patos Lagoon, Brazil. Estuaries 28(5): 675-685.

Odebrecht C, Bergesch M, MedeAnic S AND ABreU PC. 2010a. A comunidade de microalgas. In: Seeliger U and Odebrecht C (Eds), O estuário da Lagoa dos Patos: um século de transformações. Rio Grande: FURG, p. 49-63.

ODEBRECHT C, BERGESCH M, RÖRIG L AND ABREU PC. 2010b. Phytoplankton interannual variability at Cassino Beach, southern Brazil (1992-2007), with emphasis on the surf zone diatom Asterionellopsis glacialis. Estuaries Coasts 33: 570-583. 
Odebrecht C, SEgatTo AZ AND Freitas CA. 1995. Surfzone chlorophyll a variability at Cassino Beach, southern Brazil. Estuar Coast Shelf S 41: 81-90.

PACHÉS M, ROMERO I, MARTÍNEZ-GUIJARRo R, MARTí CM AND FERRER J. 2014. Changes in phytoplankton composition in a Mediterranean coastal lagoon in the Cullera Estany (Comunitat Valenciana, Spain). Water Environ J 28: 135-144.

PADISÁK J. 1993. The influence of different disturbance frequencies on the species richness, diversity and equitability of phytoplankton in shallow lakes. Hydrobiologia 249: 135-156.

PAPPAS JL AND STOERMER EF. 1996. Quantitative method for determining a representative algal sample count. J Phycol 32: 693-696.

Paturej E, GutKowska A AND Mierzejewska J. 2012. A review of biological research in the Vistula Lagoon. Oceanol Hydrobiol St 41(4): 81-88.

RAMDANI M, ELKHIATI N, FLOWER RJ, THOMPSON JR, Chouba L, KRAIEM MM, AYACHE F AND AHMED MH. 2009. Environmental influences on the qualitative and quantitative composition of phytoplankton and zooplankton in North African coastal lagoons. Hydrobiologia 622: 113131.

REYNOLDS CS. 1984. The ecology of freshwater phytoplankton. England: Cambridge University Press, 384 p.

RolOn AS, Rocha O AND MALtChIK L. 2013. Does the Lagoa do Peixe sandbar opening influence the macrophyte richness and composition in Southern Brazil wetlands? Rev Biol Trop 61(1): 409-417.

RÖRIG LR AND GARCIA VMT. 2003. Accumulations of the surf-zone diatom Asterionellopsis glacialis (CASTRACANE) ROUND in Cassino Beach, Southern Brazil, and its relationship with environmental factors. J Coastal Res SI 35: 167-177.

SANTOS CB. 2011. Assembléias de diatomáceas em sedimentos holocênicos no extremo sul do Brasil: Reconstruções paleoambientais, 115 p. (Dissertação de Mestrado/Universidade Federal do Rio Grande do Sul). (Unpublished).

SCHÄFER A, LANZER R AND PEREIRA R (Eds). 2009. Atlas socioambiental dos municípios de Mostardas, Tavares, São José do Norte, Santa Vitória do Palmar. Caxias do Sul: Educs, 367 p.

SHANNON CE AND WEAVER W. 1949. The mathematical theory of communication. Urbana: The University of Illinois Press, $125 \mathrm{p}$.

SIMONSEN R. 1974. The diatom plankton of the Indian Ocean Expedition of R/V “Meteor" 1964/1965. Forsch.-Ergeb Reihe D-Biol 19: 1-61.
TER BRAAK CJF. 1986. Canonical correspondence analysis: a new eigenvector technique for multivariate direct gradient analysis. Ecology 67: 1167-1179.

TORGAN LC. 1997. Estrutura e dinâmica da comunidade fitoplanctônica na Laguna dos Patos, Rio Grande do Sul, Brasil, em um ciclo anual, 284 p. (Tese de Doutorado/ Universidade Federal de São Carlos).

TORGAN LC, ODEBRECHT CE AND NIENCHESKI LFH. 2000. Variação espacial da estrutura de tamanho do fitoplâncton na Laguna dos Patos, sul do Brasil. Atlântica 22: 95-111.

TORGAN LC, PILlar VD AND NIENCHESKI LF. 2006. Phytoplankton associations of a coastal lagoon in south of Brazil. J Coastal Res SI 39: 1149-1151.

TRUCCOLO EC. 1993. Caracterização química da Lagoa do Peixe, RS. Rio Grande, Rio Grande do Sul, 51 p. (Monografia/Universidade Federal do Rio Grande). (Unpublished).

UTERMÖHL H. 1958. Zur Vervollkommnung der Quantitativen Phytoplankton-Methodik. Mitteilungen-Internationale Vereinigung für Theoretische und Angewandte. Limnologie 9: 1-38.

VARONA-CORDERO F, GUTIÉRREZ-MENDIETA FJ AND DEL CASTILlO AMEM. 2010. Phytoplankton assemblages in two compartmentalized coastal tropical lagoons (CarretasPereyra and Chantuto-Panzacola, Mexico). J Plankton Res 32(9): 1283-1299.

WERNER VR. 2002. Cyanophyceae/Cyanobacteria no sistema de lagoas e lagunas da planície costeira do Estado do Rio Grande do Sul, Brasil, 363 p. (Tese de Doutorado/ Universidade Estadual Paulista).

WERNER VR AND SANT'ANNA CL. 2000. A new species of Aphanothece (Cyanophyceae, Chroococcales) from a shallow coastal lagoon, south Brazil. Nova Hedwigia 70: 113-125.

WERNER VR AND SANT'ANNA CL. 2006. Occurrence of the rare genus Microcrocis P.Richter (Chroococcales, Cyanobacteria) in a coastal lagoon from southern Brazil. Rev Bras Bot 29(1): 183-186.

WetZEL RG. 1993. Limnologia. Lisboa: Fundação Calouste Gulbenkian, 919 p.

WETZEL RG AND LiKENS GE. 2000. Limnological Analyses. New York: Springer-Street, $429 \mathrm{p}$.

WONG KTM, LEE JHW AND HodGKISS IJ. 2007. A simple model for forecast of coastal algal blooms. Estuar Coast Shelf S 74: 175-196.

YIN K. 2002. Monsoonal influence on seasonal variations in nutrients and phytoplankton biomass in coastal waters of Hong Kong in the vicinity of the Pearl River estuary. Mar Ecol-Prog Ser 245: 111-122. 